\title{
Childlessness and norms of familial responsibility in the Netherlands
}

\author{
Renske Keizer $^{\mathrm{a}}$, Pearl A. Dykstra ${ }^{\mathrm{a}}$ and Anne-Rigt Poortman ${ }^{\mathrm{b}}$ \\ ${ }^{a}$ Erasmus University Rotterdam, the Netherlands \\ ${ }^{\mathrm{b}}$ University of Utrecht, The Netherlands
}




\section{Contact information:}

Dr. Renske Keizer

Erasmus University Rotterdam

Faculty of Social Sciences, Dept of Sociology

PO box 1738

3000 DR Rotterdam

Email: keizer@fsw.eur.nl

Phone: +31-10-4082719

Prof. Dr. Pearl A. Dykstra

Erasmus University Rotterdam

Faculty of Social Sciences, Dept of Sociology

PO box 1738

3000 DR Rotterdam

Email: dykstra@fsw.eur.nl

Phone: +31-10-4082076

Dr. Anne-Rigt Poortman

Utrecht University

Faculty of Social Sciences, Dept. of Sociology

PO Box 80140

3508 TC Utrecht

Email: a.poortman@uu.nl

Phone: +31-30-2534306 


\section{ABSTRACT (English)}

\section{Childlessness and norms of familial responsibility}

Using data from the second wave of the Netherlands Kinship Panel Study (NKPS) for 3069 female and 2096 male respondents, we studied differences in norms of universal and of personal familial responsibility between childless individuals and parents.

Differences depend on the type of norm studied. Childless individuals, and in most cases only those who opt voluntarily for a childless life, express weaker norms of universal familial responsibility in comparison with parents. Women's norms of personal familial responsibility do not vary by parental status. Men appear to need the presence of children to activate feelings of personal responsibility for family members. Differences between childless individuals and parents are attributable to selection rather than to adaptation. The theoretical and social implications of our findings are discussed. 


\section{ABSTRACT (French) \\ L’infécondité et les normes de responsabilités familiales}

Sur la base des données du deuxième cycle de l'enquête « Netherlands Kinship Panel Study » (NKPS) pour 2069 femmes et 2096 hommes, nous étudions les différences entre les individus inféconds et féconds en termes de normes universelles et/ou personnelles de responsabilités familiales. Nous trouvons que les différences semblent dépendre du type de norme. Les individus inféconds, et dans la plupart des cas uniquement ceux qui ont opté volontairement pour une vie sans enfant, expriment des normes plus faibles quant aux responsabilités familiales universelles en comparaison avec les parents. Pour les femmes, les normes personnelles de responsabilités familiales ne varient pas avec la présence ou l'absence d'enfants. Les hommes semblent nécessiter la présence d'enfants pour engendrer les sentiments de responsabilité personnelle face aux membres de la famille. Les différences entre les individus féconds et inféconds sont attribuables à des effets de sélection plutôt que d'adaptation. Les implications théoriques et sociales de nos résultats sont examinées. 


\section{ABSTRACT (Spanish) \\ La carencia de hijos y las normas de la responsabilidad familiar}

Usando los datos de la segunda ola del « Netherlands Kinship Panel Study » (NKPS) con 3069 encuestadas femeninas y 2096 encuestados masculinos, estudiamos las diferencias en las normas de la responsabilidad universal y de la responsabilidad personal y familiar entre los individuos sin hijos, por un lado, y los padres, por otro. Las diferencias dependen del tipo de norma estudiado. Los individuos sin hijos y, en la mayoría de los casos, sólo los que opten voluntariamente por una vida sin hijos, expresan unas normas de responsabilidad familiar más débiles en comparación con los padres. Para las mujeres, las normas de la responsabilidad familiar no varían según su estado paternal. Para los hombres, la presencia de hijos parece activar sentimientos de responsabilidad familiar hacia los miembros de la familia. Las diferencias entre los individuos sin hijos y los padres se pueden atribuir más bien a la selección que a la adaptación. Se discuten las implicaciones teóricas y sociales de nuestros resultados. 


\section{INTRODUCTION}

From the moment childlessness became a topic of scientific research, the childless have been depicted in negative terms: less well adjusted, less nurturing, more materialistic, more selfish, more individualistic and more career-oriented than parents (see for overviews Ganong, Coleman, \& Mapes, 1990; Houseknecht, 1987; Veevers, 1983). Although the growing prevalence and acceptance of childlessness among young cohorts has led to a less powerful stigma in recent decades (Koropeckyj-Cox \& Pendell, 2007; Morgan, 1996; Thornton, 1989; Thornton \& Young-DeMarco, 2001), the childless, especially those who voluntarily choose not to have children, remain stereotyped as somewhat "individualistic" people who avoid social responsibility and are less prepared to commit themselves to helping others in society (Kopper \& Smith, 2001; LaMastro, 2001; Letherby, 2002; Mueller \& Yoder, 1999). This stereotype image of the childless appears in the debate about "the decline of the family", where scholars have suggested that increased levels of childlessness contribute to declining levels of family solidarity (Bloom \& Bennett, 1986; Hunt \& Hunt, 1982). For example, it is likely that childlessness lowers affection and cohesion between adult children and their parents, especially when the former choose to remain childless, when the latter feel that the childlessness of their children hampers their own transition into grandparenthood.

Despite prevailing stereotypes of the childless, little research has actually addressed whether the childless feel less responsible for others compared to people who have children. This may be even more surprising in the light of contemporary childlessness rates. As in other countries (Abma \& Martinez, 2006; Rowland, 2007), childlessness rates have shown a steady increase among Dutch women born after the Second World War. Among those born between 1945 and 1949, 12 percent remained childless compared to 15 per cent of women born in the 1950s. Among women born in the 1960s and 1970s this percentage is likely to raise to 20 per cent (Merens \& Hermans, 2009). As one out of every five individuals in the Netherlands will never have children, answering the question whether the childless feel less responsible for others compared to people who have children has both scientific and societal relevance.

We take up this issue by examining differences in norms of familial responsibility between childless individuals and parents. Familial responsibility is an aspect of the 
broader concept of familism (Heller, 1970; 1976) and refers to felt obligations to help each other among members of a kinship group.

In the literature on intergenerational obligations (Daatland \& Herlofson, 2003; Gans \& Silverstein, 2006; Lee, Peek, \& Coward, 1998; Silverstein, Gans, \& Yang, 2006; Stein et al., 1998) childlessness has remained an understudied topic. The few studies that take the impact of parental status into account (Daatland \& Herlofson, 2003; Komter \& Vollebergh, 2002) assess childlessness in a rather crude way, merely distinguishing whether or not people have children at a particular moment.

Studies on familial responsibility norms are absent in the literature on childlessness. Focusing on attitudes about marriage, cohabitation, divorce and gender roles, the literature shows that it is important to make a distinction between different types of childlessness; childless individuals who have voluntarily opted for a life without children have less traditional values and attitudes compared to parents and involuntarily childless individuals (Bram, 1984; Bulcroft \& Teachman, 2003; Houseknecht, 1987; Jacobson \& Heaton, 1991; Veevers, 1983). It is therefore likely that people without children do not all hold similar norms of familial responsibility. For a nuanced and proper assessment of associations between childlessness and familial responsibility, we make a distinction between the childless based on volition.

We pose that taking the diversity among the childless into account not only does justice to social reality, but also advances our understanding of why childless individuals differ from parents with respect to their norms of familial responsibility. In general, the literature addresses two main underlying processes: adaptation and selection (Lesthaeghe $\&$ Moors, 2002). Differences between parents and childless individuals may be attributable to adaptation; i.e. life course events contribute to changes in previously held values (adaptation effect), either by reinforcing or by reconsidering them (Lesthaeghe \& Moors, 2002). In the context of our research question, adaptation implies that the transition to parenthood changes people's norms of familial responsibility.

Differences between parents and childless individuals may also be attributable to selection; i.e. familial responsibility norms affect the way individuals opt for specific life course pathways (Lesthaeghe \& Moors, 2002). For example, people with weak norms of familial responsibility might be less likely to become parents than those with a strong 
sense of responsibility. If selection is at play, it would be wrong to compare parents with "the" childless, given that the intentionally childless are a different group of individuals from the start (Rovi, 1994). Scholars should therefore make a distinction between childless individuals based on volition and compare these groups with parents. As prior studies on intergenerational obligations have not made such comparisons, it has not been possible to gain insight into selection and adaptation. This paper makes a distinction between the childless based on the voluntary or involuntary nature of their childless state and compares them with parents, allowing us to detect the footprints of selection and adaptation.

\section{CHILDLESSNESS AND NORMS OF FAMILIAL RESPONSIBILITY}

Predictions in two diverging directions can be made regarding the association between childlessness and norms of familial responsibility. In line with common beliefs, childless people are expected to have a weaker sense of familial responsibility compared to parents. One line of reasoning suggests that adaptation takes place: family-related issues are more highly valued when people have children than when they do not have children. Parenthood, according to Gutmann (1975), fosters greater responsibility towards one's family, as becoming a parent reaffirms moral, civic and ethical norms. This line of thinking has received empirical support. Studies show that parenthood promulgates goals in life which transcend the individual self (Barnett, Marshall, \& Pleck, 1992; Dykstra, 2006; Furstenberg, 2005) and that people become more directed towards wider circles of family, neighborhood and community after having made the transition to parenthood (e.g Belsky \& Rovine, 1984; Knoester \& Eggebeen, 2006).

Alternatively, selection may be at play. Research has shown that childless individuals who intend to remain childless are more individualistic and have a greater preference for self-selected contact compared to parents and childless individuals who intend to have children (Rovi, 1994). People with weaker norms of familial responsibility may therefore be more likely to remain childless. Note that adaptation and selection do not lead to different hypotheses. They reflect different processes that underlie the expected negative association between childlessness and a sense of obligation towards family. 
The opposing view is that childless individuals have stronger norms of familial responsibility in comparison with parents. Parenthood, like marriage (Coser, 1974; Gerstel \& Sarkisian, 2006) can be seen as a "greedy institution", directing attention away from the wider circle of family. People may adapt their feelings of familial responsibility to personal circumstances that restrict their ability to provide family care (e.g. competing demands). Therefore, the childless may feel more responsible when it comes to supporting their wider circle of family compared to people with children, as the childless do not have childrearing obligations. Supporting this view, a Dutch study studying family solidarity shows that childless individuals give somewhat more help and care to family members outside the nuclear family (Komter \& Vollebergh, 2002).

The alternative explanation - selection - is that strong norms of familial responsibility increase the likelihood that people will remain childless as the involvement with family members may be so strong and time-consuming that these individuals decide not to have children of their own. Selection is evident among women who remained childless before the 1940s; these women were often highly dedicated towards their families. The reason they had remained unmarried and therefore also childless was that they continued to live at home to care for aging parents (Dykstra \& Hagestad, 2007). Again, adaptation and selection do not lead to different hypotheses.

\section{Biases}

When analyzing people's answers to questions concerning the voluntariness of their childless state, it is important to distinguish between childless people who are in their fertile years and those who are beyond the fertile age as their answers may be biased in different ways. First, as we live in pronatalistic societies, it takes determination to state that one does not want to have children (Rovi, 1994). Social pressure may therefore lead people to answer that they would like to have children, although their true feelings may be the opposite. As a result, some people in their fertile years may answer that they intend to have children although they actually want to remain childless, clouding the category of individuals who intend to have children.

Second, to avoid dissonance, people are likely to retrospectively adjust their feelings to their actual parental status. Therefore, some people beyond their fertile years 
will answer that they are voluntarily childless although they may actually have wanted to have children, which clouds the category of individuals who perceive themselves as voluntarily childless. In sum, solely focusing on people in their fertile years may lead to distorted results among the childless who did not choose to remain childless, while solely focusing on those beyond the fertile age may lead to distorted results among those who did opt for a childless life. This implies that a reliable assessment of associations between childlessness and norms of familial responsibility requires a separate analysis of the childless both in and beyond their fertile years. Unfortunately, in the literature on childlessness, studies on associations between childlessness and general values have either focused only on childless individuals in their fertile years (see for example Bram, 1985), or only on those beyond their fertile years (Callan, 1987) or on both without making a distinction between them (Kemkes-Grottenthaler, 2003). As a result, the bias issue has not been addressed and results may therefore have been misclassified.

In this paper, we separate childless individuals in their fertile years from those beyond their fertile years and we make a distinction between the childless based on whether or not they chose to remain childless. Among those of fertile age, we distinguish between those who intend to remain childless and those who intend to have children. Among the childless beyond their fertile years, we distinguish between those who perceive themselves as voluntarily childless and those who see themselves as involuntarily childless.

\section{Distinguishing between adaptation and selection}

In the context of childlessness and familial responsibility, adaptation implies that becoming a parent serves to reinforce people's norms of familial responsibility. From an adaptation perspective, those who have made the transition to parenthood are expected to have different values from those who have not made this transition. This means that, when adaptation is at play, all childless individuals, whether by volition or not, will differ from parents in terms of their norms of familial responsibility. It also means that childless individuals who opt for a childless life do not differ from those who want, or wanted to have children. 
Selection implies that people's norms of familial responsibility affect the likelihood that they will enter parenthood. From a selection perspective, only those who opt for a childless life are expected to have distinctive norms of familial responsibility. Among the childless of fertile age, this means that only the childless who intend to remain childless will have different norms of familial responsibility compared to individuals who already have or intend to have children. Childless individuals who intend to have children are not expected to differ from parents, as the former are likely to become parents in the future. Among the childless beyond their fertile years, only those who see their childless state as voluntary will have different norms of familial responsibility compared to involuntarily childless individuals and parents. People who are involuntarily childless are not expected to differ from parents as the former embrace the parenting role in principle and are assumed to differ from parents only in terms of the fact that they have not succeeded in becoming a parent.

\section{Other characteristics}

The literature identifies several social characteristics that differentiate individuals by the strength of their norms of familial responsibility and that are associated with childlessness. The first is educational attainment. The literature is most clear on associations for women. Childless women, especially the voluntarily childless, are shown to have higher levels of education compared to mothers. This positive association is well documented both in the Netherlands (De Meester et al, 2005; Liefbroer \& Dykstra, 2000; Keizer, Dykstra \& Jansen, 2008) and in other Western countries (e.g. González \& JuradoGuerrero, 2006). The relationship between education and family norms is less clear-cut. In their review of the literature Liefbroer and Mulder (2006) conclude that the evidence is mixed; some studies show that people with higher levels of education hold stronger familial norms, while others find the opposite association. Regarding actual support, Dutch studies reveal that higher educated individuals are more prone to give emotional support to their family compared to people with lower levels of education. However, no differences in education where found with respect to instrumental help (Komter \& Vollebergh, 2002). Second, partnership status is shown to be both related to childlessness

and familial norms. Individuals who have never had a partner or who are single after 
being partnered are shown to have higher odds of being childless compared to cohabiting and especially compared to married individuals (e.g. Barber, 2001; Keizer, Dykstra \& Jansen; Kiernan, 2004). Furthermore, studies show that married individuals have stronger familial norms than unmarried individuals (Lowenstein \& Daatland, 2006), although the former do not differ from respondents who cohabit (Daatland 2007). It appears that having a partner is important here (Ward \& Spitze, 1998). Finally, it is important to consider religiosity. Not only are religious persons less likely to be childless (see f.e. Bloom \& Trussell, 1984; Veevers, 1979), but they are also more likely to express strong norms of familial responsibility (Reitsma, 2007).

\section{DATA AND METHOD}

\section{Data source}

We have used data from the second wave of the public release file of the Netherlands Kinship Panel Study (NKPS). The NKPS is a large-scale panel survey on family ties, which started in 2002 among a representative sample of adults aged 18 to 79 residing in private households in the Netherlands (Dykstra et al., 2005). The data were collected by means of computer-assisted interview schedules. Data from the first wave were collected between 2002 and 2003. The overall response rate of the first wave was $45 \%$, which is lower than in comparable surveys in other Western countries, but similar to comparable large-scale family surveys in the Netherlands (De Leeuw \& De Heer, 2001; Dykstra et al., 2005). The second wave was conducted between 2006 and 2007. The overall response rate of this wave was $74 \%$. The cooperation rate for the second wave (excluding respondents who were too ill to participate, respondents who had moved abroad or died in between the waves) was $84 \%$. We decided to make use of information from wave 2 rather than wave 1 as the first wave does not provide information on people's perceptions of their childless state. For our purposes, respondents were selected between the ages of 21 and 65. Our final sample included 5,165 respondents.

\section{Dependent Variables}

The literature on intergenerational obligations distinguishes two types of norms relating to familial responsibility. Different scholars give different names to them, but we shall 
refer to universal and personal norms (following Lee, Netzer, \& Coward, 1994). Whereas the former refer to general norms pertaining to family support giving, the latter refer to individual feelings of personal responsibility towards one's own family. In the literature, both types are conceptually distinguished (Daatland \& Herlofson, 2003; Ganong \& Coleman, 2005; Lee et al., 1994; Piercy, 1998; Silverstein et al., 2006), but previous research has studied only universal norms regarding responsibility, with the exception of Ganong \& Coleman's (2005) vignette study. Scholars have suggested that people's norms of familial responsibility may differ depending on whether they relate to universal or personal norms (Daatland \& Herlofson, 2003; Gans \& Silverstein, 2006; Lee et al., 1994; Silverstein et al., 2006). For example, even when individuals embrace the value of universal familial responsibility, they may not feel responsible to provide support themselves. To find out whether differences between childless individuals and parents depend on the type of norm, we included measures of both universal and personal familial responsibility norms in our analyses. Respondents were told explicitly that "family" in the survey context consisted of "a partner, parents, children, brothers and sisters, grandparents, grandchildren, uncles, aunts, cousins, nephews and nieces”.

Universal familial responsibility was measured using a four-item scale. Scale items are: "One should always be able to count on family", "Family members should be ready to support one another, even if they don't like each other", "If one is troubled, family should be there to provide support" and "Family members must help each other, in good times and bad". Respondents rated each item on a 5-point Likert scale. The reliability of the four items was $\alpha=.86$. Answers to these four questions were added up, potentially ranging from 4 (weak familial responsibility) up to 20 (strong familial responsibility).

Personal familial responsibility was derived from the question: "If there were a problem in your family, how responsible would you feel to solve the problem?" The responses ranged from 1 (not at all responsible) to 3 (very responsible).

\section{Independent variables}

In this paper, we analyze familial responsibility norms among childless people in and beyond their fertile years. Therefore, we make use of two separate samples of 
individuals. In the young sample, distinctions among childless individuals are based on childbearing intentions. In the survey, women under 45 and men under 50 received questions about their childbearing intentions. People without children were asked the

question: "Do you think you'll have children in the future?" Answers were 1 (yes), 2 (no), and 3 (don't know). Those without biological or adopted children who said they did not intend to have children were categorized as: intention to remain childless (175 men and 155 women). Those without biological or adopted children who said they intended to have children were placed in the category: intention to become a parent (243 men and 253 women). Women under 45 and men under 50 with biological or adopted children were categorized as parents (763 men and 1097 women). Only 48 men (4\%) and 54 women (4\%) said they did not know whether they would have children in the future. We consider these numbers to be too small to obtain reliable results and have therefore excluded these respondents from our analyses.

In the older sample, distinctions among childless individuals are based on how they perceive their childless state: 1 (voluntarily childless) and 2 (involuntarily childless). Among childless women aged 45 and over, 176 identified themselves as voluntarily childless and 142 as involuntarily childless. Among childless men aged 50 and over, 106 said they were voluntarily childless and 104 men said they were involuntarily childless. Women over 45 and men over 50 with biological or adopted children were placed in the parent category (1246 women and 705 men).

\section{Control variables.}

Information about the respondents' education was derived from the question: "What is the highest level of education you achieved?" Answers ranged from 1 (did not complete elementary school) to 11 (post-graduate).

With respect to partnership status, people were considered to have a partner if they lived with a partner. We differentiated between: 1 (never partnered), 2 (cohabiting), 3 (married), and 4 (single and formerly partnered).

Religiosity was based on the two questions: "Do you count yourself as belonging to a particular faith, religious denomination or church?" and "How often do you currently attend services of a church or community of faith?". Respondents were coded 0 when 
they were not religious. They were coded 1 when they were religious, but hardly ever went to church, 2 when they were religious and went once or a few times a year, 3 when they were religious and went once or a few times a month and finally they were coded 4 when they were religious and went once or a few times a week.

Age was measured in years. Descriptive statistics of our dependent, independent and control variables are shown in Table 1.

\section{Analytic Strategy}

To facilitate interpretation of our results, we report differences in unadjusted and adjusted means between childless individuals and parents. These means are derived from multiple classification analysis (MCA). MCA is a procedure in ANOVA (ANalysis Of VAriance). MCA examines the relationships between several categorical independent variables and a single dependent variable, and determines the effects of each predictor before and after adjustment for its inter-correlations with other predictors in the analysis (Andrews, Morgan, Sonquist \& Klem, 1973).

The means are adjusted for age, level of education, partnership status and religiosity. Results for significance tests between the groups of childless individuals and parents are discussed in the text below.

The measure for personal familial responsibility had only three answer categories and was not measured at interval level. For that reason, we ran additional analyses (not shown) with an ordered logit model. Results (available upon request) were very similar to those based on the MCA.

As mentioned, our analyses are based on two separate samples. We will first discuss the results for the respondents who are of fertile age before describing the results for those who are beyond their fertile years.

The literature shows gender differences in supportive exchanges among relatives, with women being more oriented towards their family than men (Hagestad, 1992; Komter \& Vollebergh, 2002; Marks \& McLanahan, 1993; Rosenthal, 1985; Rossi \& Rossi, 1990). This notion was confirmed by our preliminary analyses, which showed significant interaction effects for gender. We found in the group of respondents in their fertile years, that women had significantly stronger personal familial norms and significantly weaker 
universal familial responsibility norms in comparison to men. The latter finding was also found in the group of respondents beyond their fertile years. Furthermore, the relationship between parental status and familial responsibility was moderated by gender.

Involuntarily childless women reported to have stronger personal familial responsibility norms compared to involuntarily childless men. Based on the literature and the previously described results, our analyses were performed separately for women and men. First, we will discuss women's and men's universal familial responsibility norms, after which we turn to women's and men's personal familial responsibility norms. Differences between the unadjusted and the adjusted means will be explained using Table 1 and Table 2. The latter shows the standardized coefficients for our independent and control variables.

\section{RESULTS}

\section{Linkages between parental status and control variables}

Table 1 shows that there are large differences between women and men with different parental status with respect to age, educational attainment, partner status and religion. Regarding age, individuals with childbearing intentions are younger than individuals without childbearing intentions and parents. In the older sample we find that mothers and fathers are older than individuals who have not made the transition to parenthood. Mothers are lower educated than childless women. Among men, there is less variation in educational attainment, although we see that men with childbearing intentions have the highest level of education of all men. Among both women and men we find that amongst parents there are far more individuals who have a partner than amongst childless individuals. Regarding religion, we find that women without childbearing intentions are less religious than women with childbearing intentions, who are again less religious compared to mothers. The same holds for women in the older sample. For men we find that fathers are more religious than childless men. (Table 1 about here)

\section{Linkages between control variables and familial responsibility}

Table 2 reveals that age, and especially religion and educational attainment, are the most important control variables with respect to familial responsibility. Partnership status is of little importance for feelings of familial responsibility. When significant, the coefficient 
for age shows that older individuals report weaker norms of familial responsibility. Persons with a higher level of education report lower levels of universal familial responsibility, but higher levels of personal familial responsibility. Finally, the table shows that religious individuals have significantly higher norms of universal and personal familial responsibility. (Table 2 about here)

\section{Parental status and familial responsibility}

Table 3, the first set of rows, shows that childless women who intend to remain childless have significantly weaker norms of universal familial responsibility than childless women with childbearing intentions and mothers. Childless women with childbearing intentions and mothers do not differ significantly from each other. These findings hold for both the unadjusted and the adjusted means. The finding that only women who intend to remain childless differ from mothers suggests that selection is at play here.

Among women in the older sample, the second set of rows, the unadjusted means show that mothers have significantly stronger norms of universal familial responsibility compared to involuntarily and voluntarily childless women. Furthermore, the unadjusted means also show that involuntarily childless women have significantly stronger norms of universal familial responsibility compared to voluntarily childless women. This latter difference is no longer significant when we turn to our adjusted means. The explanation for the disappearance of this effect is that we controlled for educational attainment and religion. Both factors have a strong impact on universal familial responsibility and also differ strongly between the voluntarily and involuntarily childless. As a result, differences between the groups of women become smaller. When our means are adjusted for our control variables, only voluntarily childless women have significantly weaker norms of universal familial responsibility compared to mothers. Involuntarily childless women do not differ significantly from voluntarily childless women, nor do they differ significantly from mothers. These findings suggest footprints of both selection and adaptation and show that it depends on the degree of volition whether or not childless women differ from mothers in terms of their universal familial responsibility norms. Childless women have weaker norms of familial responsibility compared to mothers when their childless state is of their own volition. 
The third and fourth set of rows in Table 3 details men's universal familial responsibility norms. The third set of rows, our younger sample, shows that men who intend to remain childless have a significantly weaker sense of universal familial responsibility compared to fathers and men who intend to become fathers. These two latter groups do not differ significantly from each other. These findings hold for both the unadjusted and the adjusted means. The finding that only men who intend to remain childless differ from fathers suggests that selection is at play here. Among men in our older sample, we find that voluntarily childless men, involuntarily childless men and fathers do not differ significantly from each other in terms of their norms of universal familial responsibility. These findings hold for both the unadjusted and the adjusted means. (Table 3 about here)

In Table 4 we turn to personal familial responsibility. The first set of rows shows no significant differences between women in our younger sample. These findings hold for both the unadjusted and the adjusted means. When we focus on women in the older sample, the unadjusted means show that voluntarily childless women do not significantly differ from mothers. Furthermore, the unadjusted means show that involuntarily childless women have significantly stronger norms of personal familial responsibility compared to mothers and voluntarily childless women. This latter difference is no longer significant when we turn to our adjusted means. The explanation for the disappearance of this effect is that we controlled for educational attainment and religion. Both factors have a strong impact on personal familial responsibility and also differ strongly between the voluntarily and involuntarily childless. As a result, differences between the groups of women become smaller. When our means are adjusted for our control variables, differences between the groups of women are no longer significant. When it comes to their sense of responsibility towards their own families, childless women and mothers appear to be quite similar.

The last two sets of rows in Table 4 show men's personal familial responsibility norms. Looking at the third set of columns, the younger sample of men, we see that childless men who intend to remain childless have a significantly weaker sense of personal familial responsibility than fathers. Childless men who intend to have children in the future do not differ from childless men who intend to remain childless, nor do they differ from fathers in terms of their norms of personal familial responsibility. These 
findings hold for both the unadjusted and the adjusted means. These findings suggest footprints of both selection and adaptation.

Turning to the older sample in the final set of rows, the unadjusted means show that voluntarily childless men do not significantly differ from fathers. Furthermore, the unadjusted means show that involuntarily childless men have significantly weaker norms of personal familial responsibility compared to fathers and voluntarily childless men. These findings change when we look at our adjusted means. There we find that both voluntarily and involuntarily childless men have significantly weaker norms of personal familial responsibility. The explanation for this change is that we controlled for educational attainment. Voluntarily childless men are highly educated and the higher a man is educated the stronger his personal familial norms. Controlling for educational attainment lowers the mean for voluntarily childless men. When our means are adjusted for our control variables, both voluntarily and involuntarily childless men have significantly weaker norms of personal familial responsibility than fathers. Voluntarily and involuntarily childless men do not differ significantly from each other. The finding that they differ from fathers suggests that adaptation is at play here. Permanently childless men, regardless of the degree of volition, have a weaker sense of personal familial responsibility than fathers. (Table 4 about here)

\section{CONCLUSION AND DISCUSSION}

The first aim of this paper was to find out whether childless people have weaker norms of familial responsibility than parents. In order to properly analyze differences between childless individuals and parents, we distinguished two types of childless people based on volition. We found that not all individuals without children have weaker norms of familial responsibility. Where differences were found, they indicated, with one exception, that only childless people who choose, or have chosen to remain childless have a weaker sense of responsibility. These findings underline the importance of knowing the degree of volition in order to fully understand differences between parents and people who are childless. As others have suggested, a subjective definition of not having children is crucial to accurate assessment of childlessness in people's lives (Connidis \& Campbell, 1995). 
Making a distinction between voluntarily and involuntarily childless people has enabled us to find out whether selection or adaptation underlies differences in norms of familial responsibility. We found most evidence for selection. Only those who voluntarily opt for a childless life, not those who want or wanted to have children, were shown to have weaker norms of familial responsibility than parents. We found strong adaptation among older men: norms of personal familial responsibility were much stronger among fathers than among both voluntarily and involuntarily childless men. An explanation might be that the transition to fatherhood has led men to think solely of "family" as their nuclear family, rather than seeing family as the wider circle of family members. As feelings of family obligation have been shown to be stronger for close family and to decrease with a lower level of relatedness (Rossi \& Rossi, 1990), fathers - with their children in mind - may have expressed stronger feelings of familial responsibility than childless men.

Becoming a parent serves to reinforce men's norms of personal familial responsibility. Among women, by contrast, parental status appears to be of little importance when it comes to their personal feelings of responsibility. Previous research has consistently shown that women have a special role as kin keepers who sustain family contacts and tend to be more family-oriented than men (Hagestad, 1992; Komter \& Vollebergh, 2002; Marks \& McLanahan, 1993; Rosenthal, 1985; Rossi \& Rossi, 1990). So whereas women were found to always feel responsible for their own families, men appear to need the presence of children to activate the significance of family in their own personal lives.

In contrasting universal with personal norms of familial responsibility, we found differences between childless individuals and parents. Interesting results were found for women. Although voluntarily childless women do not have weaker expressions of personal familial responsibility than mothers, they do have a weaker sense of universal familial responsibility compared to mothers. It appears that voluntarily childless women do not want to impose responsibility on others. This fits with the notion that voluntarily childless individuals have individualistic attitudes and believe that everybody should decide for themselves how responsible they want to be (Kopper \& Smith, 2001; LaMastro, 2001; Letherby, 2002; Mueller \& Yoder, 1999). 
Our attempt to contrast universal with personal familial responsibility norms is a first step towards studying differences between universal and personal familial responsibility in a large-scale survey study. Our measure for personal familial responsibility was based on only one item, with a range of no more than three answer categories. A measure that consists of more items might be more reliable. Future research that takes into account more elaborate measures of personal familial responsibility would be a welcome addition to the literature on intergenerational obligations.

Furthermore, family is a broad concept. Specifying the conceptualization of family to the respondents has the advantage of comparability across respondents .Despite the fact that respondents were told explicitly that "family" in the survey context consisted of "a partner, parents, children, brothers and sisters, grandparents, grandchildren, uncles, aunts, cousins, nephews and nieces", we cannot rule out the possibility that respondents differed in their conceptions of family. It is conceivable that some thought only of their family of origin, others thought of their family of procreation and yet others of the extended family.

In this paper we started off by observing that in the literature the childless tend to be depicted as lacking social responsibility. Our results showed that on the whole childless individuals and parents do not differ strongly in terms of familial responsibility. But when they do, only those who are childless by choice tend to have weaker norms of familial responsibility. Despite these "individualistic" characteristics, childless women were not found to express less responsibility towards their own families. In other words, what people feel family members in general should do for their families does not necessarily tally with what they feel they themselves should do for their own families. Our research shows that women, irrespective of their parental status, feel personally responsible for their own families. This finding does not substantiate the socially constructed image of the childless as being selfish and individualistic. Only men were found to need children of their own to activate the significance of family in their personal lives. As women are the kin keepers of the family, and as childless women were found to feel as responsible for their own family members as mothers, our study did not yield evidence for the claim that increasing rates of childlessness contribute to declining levels of family solidarity. 


\section{ACKNOWLEDGEMENTS}

This research was funded by the Netherlands Organization for Scientific Research (NWO); grant number 457-03-012, under the program "The ties that bind" (BKF). The data for this paper from the Netherlands Kinship Panel Study (NKPS), which is funded by the "Major Investments Fund" of the Netherlands Organization for Scientific Research (NWO), under grant 480-10-009. Financial and institutional support for the NKPS also came from The Netherlands Interdisciplinary Demographic Institute (NIDI), the Faculty of Social Sciences of Utrecht University, the Faculty of Social and Behavioral Sciences of the University of Amsterdam, the Faculty of Social Sciences of Tilburg University, and the Faculty of Social Sciences of the Erasmus University Rotterdam. We would like to thank Anne Gauthier and Pepijn de Boer for translating the abstracts in French and Spanish respectively. 


\section{REFERENCES}

Abma, J. C., \& Martinez, G. M. (2006). Childlessness among older women in the United States: Ttrends and profiles. Journal of Marriage and Family, 68(4), 1045-1056.

Andrews, F. M., J. N. Morgan, J. A. Sonquist and L. Klem (1973). Multiple classification analysis. Second edition. Ann Arbor: Institute for Social Research, The University of Michigan.

Barber, J. S. (2001). Ideational influences on the transition to parenthood: Attitudes towards childbearing and competing alternatives. Social Psychology Quarterly, 64(2), 101-127.

Barnett, R. C., Marshall, N. L., \& Pleck, J. H. (1992). Men's multiple roles and their relationship to men's psychological distress. Journal of Marriage and the Family, 54(2), 358-367.

Belsky, J. \& Rovine, M. (1984). Social-Network Contact, Family Support, and the Transition to Parenthood. Journal of Marriage and Family, 46 (2), pp 455-462

Bloom, D. E., \& Bennett, N. (1986). Childless couples. American Demographics, 23(8), $22-25$.

Bloom, D. E., \& Trussell, J. (1984). What are the determinants of delayed childbearing and permanent childlessness in the United States? Demography, 21(4), 591-611.

Bram, S. (1984). Voluntarily childless women: Traditional or nontraditional? Sex Roles, 10(3/4), 195-206.

Bram, S. (1985). Childlessness revisited: A longitudinal study of voluntarily childless couples, delayed parents and parents. Journal of Family and Economic Issues, 8(1), 4666.

Bulcroft, R., \& Teachman, J. (2003). Ambiguous constructions: Development of a childless or childfree life course. In M. Coleman \& L. H. Ganong (Eds.), Handbook of contemporary families: Considering the past, contemplating the future. (pp. 116-135). London: Sage.

Callan, V. J. (1987). The personal and marital adjustment of mothers and of voluntarily and involuntarily childless wives. Journal of Marriage and the Family, 49(4), 847-856.

Connidis, I. A., \& Campbell, L. D. (1995). Closeness, Confiding, and Contact Among Siblings in Middle and Late Adulthood. Journal of Family Issues, 16(6), 722-745.

Coser, L. A. (1974). Greedy institutions: Patterns of undivided commitment. New York: Free Press. 
Daatland, S.O. (2007). Marital history and intergenerational solidarity: The impact of divorce and unmarried cohabitation. Journal of Social Issues, 63 (4), p809-825

Daatland, S. O., \& Herlofson, K. (2003). 'Lost solidarity' or 'changed solidarity': A comparative European view of normative family solidarity. Ageing and Society, 23(2003), 537-560.

De Leeuw, E. D., \& De Heer, W. (2001). Trends in household survey nonresponse: A longitudinal and international comparison. In R. M. Groves, D. A. Dillman, J. L. Eltinge \& R. J. A. Little (Eds.), Survey nonresponse (pp. 41-54). New York: Wiley.

De Meester, E., Esveldt, I., Mulder, C. H., \& Beets, G. (2005). De invloed van levensloopkenmerken en waardeoriëntaties op vrijwillige kinderloosheid [The influence of life course characteristics and value orientations on voluntary childlessness]. Mens en Maatschappij, 80(2), 119-142.

Dykstra, P. A., \& Hagestad, G. O. (2007). Childlessness and parenthood in two centuries; Different roads-different maps? Journal of Family Issues, 28(11), 1518-1532.

Dykstra, P. A. (2006). Off the beaten track: Childlessness and social integration in late life. Research on Aging, 28(6), 749-767.

Dykstra, P. A., Kalmijn, M., Knijn, T. C. M., Komter, A. E., Liefbroer, A. C., \& Mulder, C. H. (2005). Codebook of the Netherlands Kinship Panel Study, a multi-actor, multimethod panel study on solidarity in family relationships. Wave 1. NKPS Working paper NO.1. The Hague: Netherlands Interdisciplinary Demographic Institute.

Furstenberg, F. F. (2005). Banking on families: How families generate and distribute social capital. Journal of Marriage and Family, 67(4), 809-821.

Ganong, L. H., \& Coleman, M. (2005). Measuring intergenerational obligations. Journal of Marriage and Family, 67(4), 1003-1011.

Ganong, L. H., Coleman, M., \& Mapes, D. (1990). A meta-analytic review of family structure stereotypes. Journal of Marriage and the Family, 52(2), 287-297.

Gans, D., \& Silverstein, M. (2006). Norms of filial responsibility for aging parents across time and generations. Journal of Marriage and Family, 68(4), 961-976.

Gerstel, N., \& Sarkisian, N. (2006). Marriage: The good, the bad, and the greedy. Contexts, 5(4), 16-21.

González, M.-J., \& Jurado-Guerrero, T. (2006). Remaining childless in affluent economies: A comparison of France, West-Germany, Italy, and Spain, 1994-2001. European Journal of Population, 22(4), 317-352. 
Gutmann, D. (Ed.). (1975). Parenthood: A key to the comparative study of the life cycle. New York: Academic press.

Hagestad, G. O. (1992). Family networks in an aging society: Some reflections and explorations. In W. J. A. van der heuvel, R. Illsley, A. Jamieson \& C. P. M. Knipscheer (Eds.), Opportunities and challenges in an aging society. Amsterdam: North Holland.

Heller, P. L. (1970). Familism scale. A measure of family solidarity. Journal of Marriage and the Family, 32(1), 73-80.

Heller, P. L. (1976). Familism scale: Revalidation and revision. Journal of Marriage and the Family, 38(3), 423-429.

Houseknecht, S. K. (Ed.). (1987). Voluntary childlessness. New York: Plenum Press.

Hunt, J. G., \& Hunt, L. L. (1982). The dualities of careers and families: New integrations or new polarizations? Social Problems, 29(5), 499-510.

Jacobson, C. K., \& Heaton, T. B. (1991). Voluntary childlessness among American men and women in the late 1980s. Social Biology, 38(1/2), 79-93.

Keizer, R., Dykstra, P. A., \& Jansen, M. D. (2008). Pathways into childlessness:

Evidence of gendered life course dynamics. Journal of Biosocial Science, 40(6), 863-878.

Kemkes-Grottenthaler, A. (2003). Postponing or rejecting parenthood? Results of a survey among female academic professionals. Journal of Biosocial Science, 35(2), 213226.

Kiernan, K. (2004). Changing European families: Trends and issues. In J. Scott, J. Treas \& M. Richards (Eds.), The Blackwell companion to the sociology of families (pp. 17-33). Oxford: Blackwell Publishing.

Knoester, C., \& Eggebeen, D. J. (2006). The effects of the transition to parenthood and subsequent children on men's well-being and social participation. Journal of Family Issues, 27(11), 1532-1560.

Komter, A. E., \& Vollebergh, W. A. M. (2002). Solidarity in Dutch families. Family ties under strain? Journal of Family Issues, 23(2), 171-188.

Kopper, B. A., \& Smith, M. S. (2001). Knowledge and attitudes towards infertility and childless couples. Journal of Applied Social Psychology, 2001(31), 2275-2291.

Koropeckyj-Cox, T., \& Pendell, G. (2007). Attitudes about childlessness in the United Sates: Correlates of positive, neutral and negative responses. Journal of Family Issues, 2007(28), 1054-1080. 
LaMastro, V. (2001). Childless by choice? Attributions and attitudes concerning family size. Social Behavior and Personality, 2001(29), 231-244.

Lee, G. R., Netzer, J. K., \& Coward, R. T. (1994). Filial responsibility expectations and patterns of intergenerational assistence. Journal of Marriage and the Family, 56(3), 559565.

Lee, G. R., Peek, C. W., \& Coward, R. T. (1998). Race differences in filial responsibility expectations among older parents. Journal of Marriage and the Family, 60(2), 404-412.

Lesthaeghe, R., \& Moors, G. (2002). Life course transitions and value orientations: selection and adaptation (No. NIDI-CBGS publication No. 37). The Hague and Brussels: NIDI and CBGS.

Letherby, G. (2002). Childless and bereft?: Stereotypes and realities in relation to "voluntary" and "involuntary" childlessness and womanhood. Sociological Inquiry, 72(1), 7-20.

Liefbroer, A.C., \& Mulder, C.H. (2006). Family obligations. In: Dykstra, P.A., Kalmijn, M., Knijn, T.C.M., Komter, A.E., Liefbroer, A.C., \& Mulder, C.H. (eds). Family Solidarity in the Netherlands. Amsterdam: Dutch University Press.

Liefbroer, A. C., \& Dykstra, P. A. (2000). Levenslopen in verandering. Een studie naar ontwikkelingen in de levenslopen van Nederlanders geboren tussen 1900 en 1970. [Changing life courses. A study on the developments in the life courses of Dutch born between 1900 and 1970]. The Hague: SDU.

Lowenstein, A. \& Daatland, S.O. (2006). Filial norms and family support in a comparative cross-national context: evidence from the OASIS study. Ageing \& Society, 26 (2), 203-223

Marks, N. F., \& McLanahan, S. S. (1993). Gender, family structure, and social support among parents. Journal of Marriage and the Family, 55(2), 481-493.

Merens, A \& Hermans, B (2009). Emancipatiemonitor 2008 [Emancipation monitor 2008]. The Hague: Sociaal en Cultureel Planbureau/Centraal Bureau voor de Statistiek.

Morgan, S. P. (1996). Characteristic features of modern American fertility. Population and Development Review, 22(Suppl.), 19-63.

Mueller, K. A., \& Yoder, J. D. (1999). Stigmatization of non-normative family size status. Sex Roles, 1999(41), 901-919.

Piercy, K. W. (1998). Theorizing about family caregiving: The role of responsibility. Journal of Marriage and the Family, 60(1), 109-118. 
Reitsma, J. (2007). Religiosity and solidarity. Dimensions and relationships disentangled and tested. University of Nijmegen, The Netherlands.

Rosenthal, C. J. (1985). Kinkeeping in the familial division of labor. Journal of Marriage and the Family, 47(4), 965-974.

Rossi, A. S., \& Rossi, P. H. (1990). Of human bonding: parent-child relations across the life course. New York: Aldine de Gruyter.

Rovi, S. (1994). Taking "no" for an answer: Using negative reproductive intentions to study the childless/childfree. Population Research and Policy Review, 13(4), 343-365.

Rowland, D. T. (2007). Historical trends in childlessness. Journal of Family Issues, 28(10), 1311-1337.

Silverstein, M., Gans, D., \& Yang, F. M. (2006). Intergenerational support to ageing parents: the role of norms and needs. Journal of Family Issues, 27(2006), 1068-1084.

Stein, C. H., Wemmerus, V. A., Ward, M., Gaines, M. E., Freeberg, A. L., \& Jewell, T. C. (1998). "Because they're my parents": An intergenerational study of felt obligation and parental caregiving. Journal of Marriage and the Family, 60(3), 611-622.

Thornton, A. (1989). Changing attitudes towards family issues in the United States. Journal of Marriage and Family, 51(4), 873-893.

Thornton, A., \& Young-DeMarco, L. (2001). Four decades of trends in attitudes toward family issues in the United States: The 1960s through the 1990s. Journal of Marriage and Family, 63(4), 1009-1037.

Veevers, J. E. (1983). Voluntary childlessness: A critical assessment of the research. In E. D. Mackin \& R. H. Rubin (Eds.), Contemporary Families and Alternative Lifestyles: Handbook on Research and Theory (pp. 75-96). London: Sage Publications.

Veevers, J. E. (1979). Voluntary childlessness: a review of issues and evidence. Marriage and family review, 2(2), 1-26.

Ward, R., and Spitze, G. (1998) 'Sandwiched marriages: The implications of child and parent relations for marital quality in midlife', Social Forces, 77, 647-66 
Table 1. Descriptive Statistics of the Dependent, Independent and Control Variables, by Parental Status and Gender

\begin{tabular}{|c|c|c|c|c|c|c|c|}
\hline & & $\begin{array}{l}\text { Universal } \\
\text { norms }\end{array}$ & $\begin{array}{l}\text { Personal } \\
\text { norms }\end{array}$ & Age & $\begin{array}{l}\text { Level of } \\
\text { education }^{a}\end{array}$ & $\begin{array}{l}\text { Partnership } \\
\text { status }^{\text {b }}\end{array}$ & Religious $^{\mathrm{c}}$ \\
\hline Women & No childbearing intentions & 13.61 & 2.26 & 37.70 & 7.82 & 0.41 & 0.46 \\
\hline Below 45 & Intentions & 14.76 & 2.35 & 28.40 & 8.26 & 0.54 & 0.88 \\
\hline$(n=1505)$ & Mothers & 14.49 & 2.33 & 37.12 & 6.86 & 0.86 & 1.03 \\
\hline Men & No childbearing intentions & 14.30 & 2.16 & 40.87 & 7.11 & 0.49 & 0.73 \\
\hline Below 50 & Intentions & 14.98 & 2.23 & 30.76 & 7.56 & 0.41 & 0.62 \\
\hline$(n=1181)$ & Fathers & 14.79 & 2.29 & 40.99 & 7.17 & 0.93 & 1.09 \\
\hline Women & Voluntarily childless & 13.08 & 2.25 & 50.34 & 7.70 & 0.44 & 0.61 \\
\hline Aged $45+$ & Involuntarily childless & 13.83 & 2.31 & 51.91 & 7.44 & 0.43 & 1.02 \\
\hline$(n=1564)$ & Mothers & 14.50 & 2.20 & 54.04 & 5.94 & 0.75 & 1.21 \\
\hline Men & Voluntarily childless & 14.39 & 2.14 & 53.23 & 7.39 & 0.42 & 0.78 \\
\hline Aged 50+ & Involuntarily childless & 14.69 & 2.08 & 53.65 & 6.69 & 0.46 & 0.88 \\
\hline$(n=915)$ & Fathers & 14.74 & 2.24 & 57.21 & 6.77 & 0.85 & 1.22 \\
\hline
\end{tabular}

Note: ${ }^{a} 1$ (did not complete elementary school; 11 (post-graduate) ${ }^{\mathrm{b}}$ Proportion having a partner. ${ }^{c} 0$ not religious; 1 religious, hardly ever go; 2 religious, once or a few times a year; 3 religious, once or a few times a month; 4 religious, once or a few times a week. 
Table 2: Standardized Coefficients of Independent and Control Variables on Universal and Personal Familial Responsibility

\begin{tabular}{|c|c|c|c|c|}
\hline & \multicolumn{2}{|c|}{ Women } & \multicolumn{2}{|c|}{ Men } \\
\hline Variables & Universal & Personal & Universal & Personal \\
\hline \multicolumn{5}{|l|}{ Respondents in fertile years } \\
\hline No childbearing intentions & $-0.76^{* *}$ & -.023 & -.060 & -.069 \\
\hline Childbearing intentions & -0.34 & .005 & .012 & -.010 \\
\hline Parents & (ref) & (ref) & (ref) & (ref) \\
\hline Age & $-.149 * * *$ & -.014 & -.065 & .003 \\
\hline Educational attainment & $-.138 * * *$ & $.089 * * *$ & $-.116 * * *$ & $.085 * *$ \\
\hline Never partnered & .040 & -.036 & .016 & -.033 \\
\hline Cohabiting & .038 & -.013 & .011 & -.032 \\
\hline Married & (ref) & (ref) & (ref) & (ref) \\
\hline Single, formerly partnered & .035 & -.029 & .006 & -.036 \\
\hline Religious & $.127 * * *$ & $.056^{*}$ & $.153 * * *$ & $.077 *$ \\
\hline \multicolumn{5}{|l|}{$\begin{array}{l}\text { Respondents beyond fertile } \\
\text { years }\end{array}$} \\
\hline Voluntarily childless & $-.123 * * *$ & -.006 & .014 & -.066 \\
\hline Involuntarily childless & -.051 & .031 & .022 & $-.076^{*}$ \\
\hline Parents & (ref) & (ref) & (ref) & (ref) \\
\hline Age & -.009 & $-.082 * *$ & .063 & -.033 \\
\hline Educational attainment & $-.135 * * *$ & $.127 * * *$ & $-.132 * * *$ & $.159 * * *$ \\
\hline Never partnered & .036 & -.024 & -.006 & -.034 \\
\hline Cohabiting & -.030 & .026 & -.062 & -.009 \\
\hline Married & (ref) & (ref) & (ref) & (ref) \\
\hline Single, formerly partnered & $.054 *$ & -.035 & .013 & $-.075^{*}$ \\
\hline Religious & $.108 * * *$ & $.072 * *$ & $.130 * * *$ & $.147 * * *$ \\
\hline
\end{tabular}

Note: ${ }^{*} p<0.05 ; * * p<0.01 ; * * * p<0.001$ 
Table 3: Unadjusted and Adjusted Means and Tests of Significance for Universal Responsibility (Adjusted Deviations between Brackets)

\begin{tabular}{lcccc}
\hline Variables & \multicolumn{2}{c}{ Unadjusted Means } & \multicolumn{2}{c}{ Adjusted Means } \\
\hline Women & & & & \\
Aged below 45 & & & & \\
No childbearing intentions & $13.61^{\mathrm{a}}$ & $(-0.83)$ & $13.96^{\mathrm{a}}$ & $(-0.48)$ \\
Childbearing intentions & $14.76^{\mathrm{b}}$ & $(0.32)$ & $14.38^{\mathrm{b}}$ & $(-0.06)$ \\
Mothers & $14.48^{\mathrm{b}}$ & $(0.04)$ & $14.52^{\mathrm{b}}$ & $(0.08)$ \\
& & & & \\
Aged 45 and above & & & & \\
Voluntary childless & $13.05^{\mathrm{a}}$ & $(-1.22)$ & $13.42^{\mathrm{a}}$ & $(-0.85)$ \\
Involuntary childless & $13.82^{\mathrm{b}}$ & $(-0.46)$ & 14.07 & $(-0.20)$ \\
Mothers & $14.50^{\mathrm{c}}$ & $(0.22)$ & $14.41^{\mathrm{b}}$ & $(0.14)$ \\
& & & & \\
Men & & & & \\
Aged below 50 & & & & \\
No childbearing intentions & $14.30^{\mathrm{a}}$ & $(-0.46)$ & $14.38^{\mathrm{a}}$ & $(-0.36)$ \\
Childbearing intentions & $14.98^{\mathrm{b}}$ & $(0.22)$ & $14.89^{\mathrm{b}}$ & $(-0.14)$ \\
Fathers & $14.79^{\mathrm{b}}$ & $(0.03)$ & $14.78^{\mathrm{b}}$ & $(0.04)$ \\
& & & & $(-0.04)$ \\
Aged 50 and above & & & & \\
Voluntary childless & 14.40 & $(-0.30)$ & 14.77 & $(0.08)$ \\
Involuntary childless & 14.70 & $(-0.00)$ & 14.91 & $(0.22)$ \\
Fathers & 14.73 & $(0.05)$ & & \\
\hline & & & & \\
\hline
\end{tabular}

Note: Means with different superscripts differ significantly at the $p<.01$ level 
Table 4: Adjusted Means and Tests of Significance for Personal Responsibility (Adjusted Deviations between Brackets)

\begin{tabular}{lcccc}
\hline Variables & \multicolumn{2}{l}{ Unadjusted Means } & \multicolumn{2}{l}{ Adjusted Means } \\
\hline Women & & & & \\
Aged below 45 & & & & \\
No childbearing intentions & 2.26 & $(-0.06)$ & 2.26 & $(-0.06)$ \\
Childbearing intentions & 2.35 & $(0.02)$ & 2.32 & $(-0.04)$ \\
Mothers & 2.33 & $(0.00)$ & 2.33 & $(0.01)$ \\
& & & & \\
Aged 45 and above & & & & \\
Voluntary childless & $2.24^{\mathrm{a}}$ & $(0.03)$ & 2.19 & $(-0.03)$ \\
Involuntary childless & $2.32^{\mathrm{b}}$ & $(0.10)$ & 2.26 & $(0.04)$ \\
Mothers & $2.20^{\mathrm{a}}$ & $(-0.01)$ & 2.22 & $(-0.00)$ \\
& & & & \\
Men & & & & \\
Aged below 50 & & & & \\
No childbearing intentions & $2.16^{\mathrm{a}}$ & $(-0.10)$ & $2.17^{\mathrm{a}}$ & $(-0.09)$ \\
Childbearing intentions & 2.23 & $(-0.03)$ & 2.24 & $(-0.02)$ \\
Fathers & $2.29^{\mathrm{b}}$ & $(0.03)$ & $2.28^{\mathrm{b}}$ & $(0.03)$ \\
& & & & $(-0.03)$ \\
Aged 50 and above & & & & \\
Voluntary childless & $2.14^{\mathrm{a}}$ & $(-0.07)$ & $2.11^{\mathrm{a}}$ & $(-0.09)$ \\
Involuntary childless & $2.07^{\mathrm{b}}$ & $(-0.13)$ & $2.07^{\mathrm{a}}$ & $(-0.13)$ \\
Fathers & $2.23^{\mathrm{a}}$ & $(0.03)$ & $2.24^{\mathrm{b}}$ & $(0.03)$ \\
\hline & & & & \\
\hline
\end{tabular}

Note: Means with different superscripts differ significantly at the $p<.01$ level 